\title{
The mobile application software design research about the college students' class notes based on mental model
}

\author{
Shangshang Zhu ${ }^{1}$, Bengbeng Shi ${ }^{1}$
}

${ }^{1}$ Liuhe Road No. 288, Zhejiang University of Technology, Hangzhou, Zhejiang, 310023, China

Keywords: mental model, class notes, mobile applications.

\begin{abstract}
Personal qualities of college students crucially depend on the learning conditions of themselves. As an important tool for learning of college students, taking notes in classroom is one learning strategy frequently adopted by college students during their learning in class. With the rapid development of internet and mobile applications, college students' understandings and requirements of the class notes will also change. According to the important role of mental model in User Research, starting from Behavior Affinity Diagram in the mental model, this paper obtains the mental models of college students' class notes by way of focus group, observation and interview, and then designs and develops a Mobile App of college students' class notes, so as to satisfy their demands of class notes and help them to study better.
\end{abstract}

\section{Introduction}

In the background of information society, college students face a series of difficulties and pressures such as a large amount of information, blundering social climate, employment difficulties and so on. College students' personal qualities depend on their own learning situations. Classroom teaching as a basic teaching form of institutions of higher learning is always in a core position in the development of higher education. Taking class notes is one of the commonly used learning strategies in classroom learning and is one important tool in college students' learning. In the past few years, the mobile internet is becoming a hot spot of global concern. All kinds of mobile internet services and mobile applications have been rapidly developed and have become an indispensable part of people's life. Accordingly, college students' understandings and requirements of the class notes will also change.

Mental model [1] is a theory about the cognition. Both the digging in the human cognitive model and the digging in the user experience demand are in order to do the research about users' perceptions and users' use habits [2, 3]. If all the functional requirements of the product match the users' mental model about the product, the users will operate happily and smoothly and will be happy to use the product.

From the perspective of mental model, this paper obtains the mental models of college students' class notes by way of focus group, observation, and interview. Then design a mobile application of class notes according to the mental models of college students' class notes. If the students use the mobile application of college students' class notes, they will take notes better and study better.

\section{Research about mental model}

In the late 1970s, Princeton university professor Johnson - Laird began to conceive the mental model theory inspired by some views from the Kenneth J. W. Craik's book The Nature of Explanation [1] which was published in 1943. In 1983, Johnson - Laird systematically expounded the basic points of the theory in his book Mental Models: Towards a Cognitive Science of Language, Inference and Consciousness [4]. Mental model is considered to be a real, hypothetical or imaginative mental representation of the external reality. Once formed, mental model will affect the person's cognition and decision making and replace analysis in some situations in order to save time and energy.

The study of mental model mainly concentrated on human ergonomics and cognitive science (especially cognitive psychology) these two areas [5]. But looking from the current research, mental 
model has been used to many other disciplines. On the basis of cognitive psychology, however, there are differences in the definition and attention levels in different fields [6].

According to different areas and levels, the research methods of mental model are also different. Indi Young's definition of mental model is: people's motivation, thinking process, and the changing of feeling and thinking during the action. Indi Young argues that mental model can be shown with a series of Behavior Affinity Diagram. And the Behavior Affinity Diagram is a visualization way to show the dates of the target users' behaviors [7], as shown in Fig. 1. Above the horizontal axis, each part separated by the vertical axis (Get Dressed, Awaken Myself, etc.) is a mental space, and each mental space is divided into several parts. Under the horizontal axis, the product or product features are corresponding to each mental space. These two spaces (the space above and under the horizontal axis) constitute a complete mental model. And you can find some weaknesses of your product or product functions by comparing.

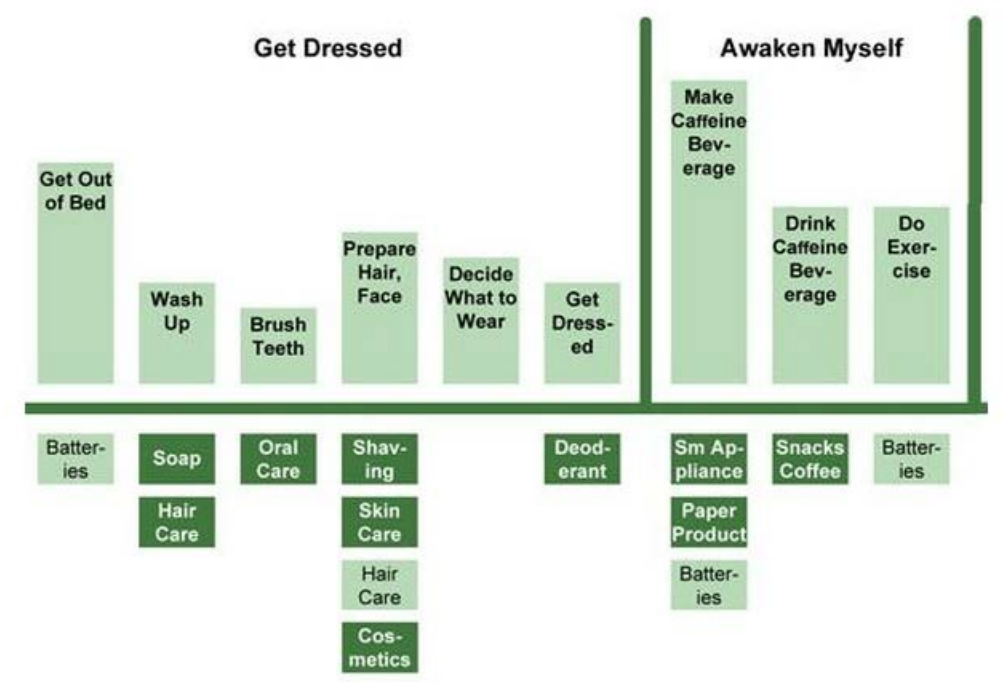

Fig. 1 Indi Young’s Behavior Affinity Diagram

\section{The study about the obtainment to the mental models of college students' class notes}

This study is aimed at the mental models of college students' class notes and the research method of Behavior Affinity Diagram can divide and render the class notes behaviors of college students very well. In order to do the research meticulously and deeply, this study takes the Behavior Affinity Diagram as a form. Then this study takes the undergraduate students of Art Institute of Zhejiang University of Technology majoring in industrial design as the research object to do the preliminary exploration research about the mental models of college students' class notes. The process of obtainment of the college students' class notes mental models is shown in Table 1. 
Table 1 The process of the obtainment of class notes mental models

\begin{tabular}{|l|l|l|l|}
\hline Process & Method & $\begin{array}{l}\text { The Experimental Process } \\
\text { Overview }\end{array}$ & Purpose \\
\hline $\begin{array}{l}\text { a mental space } \\
\text { anstruction of }\end{array}$ & Focus group & $\begin{array}{l}\text { Invite } 8 \text { junior industrial } \\
\text { design students as the research } \\
\text { team. Write down the words } \\
\text { of one's own one day } \\
\text { activities with "one day" as } \\
\text { the theme. Group merge, } \\
\text { streamline and classify the } \\
\text { vocabularies, finally obtain } \\
\text { three parts, 14 groups of } \\
\text { words. }\end{array}$ & $\begin{array}{l}\text { Provide the foundation } \\
\text { for the subsequent } \\
\text { construction of a } \\
\text { typical scene }\end{array}$ \\
\hline $\begin{array}{l}\text { The construction of } \\
\text { a typical scene }\end{array}$ & $\begin{array}{l}\text { Observation and } \\
\text { Interview }\end{array}$ & $\begin{array}{l}\text { Observe one freshman class } \\
\text { and one sophomore class } \\
\text { majoring in industrial design } \\
\text { according to the key words in } \\
\text { the mental space and interview } \\
\text { 4 students of them. Merge and } \\
\text { sort to get 10 typical scenes }\end{array}$ & $\begin{array}{l}\text { Prepare the interview } \\
\text { outline according to } \\
\text { the 10 typical scenes }\end{array}$ \\
\hline $\begin{array}{l}\text { The construction of } \\
\text { a role model }\end{array}$ & $\begin{array}{l}\text { Interview } \\
\text { Interview 4 freshman students, } \\
\text { 3 sophomore students, 3 junior } \\
\text { students majoring in industrial } \\
\text { design according to the } \\
\text { interview outline. Integrate } \\
\text { and analysis to get 3 kinds of } \\
\text { role model. }\end{array}$ & $\begin{array}{l}\text { Determine the design } \\
\text { key points based on } \\
\text { the characteristics of } \\
\text { role model }\end{array}$ \\
\hline
\end{tabular}

\section{The construction of a mental space}

Through the method of focus group, this study divides the mental space into three parts, namely, preparation before class, record in class and extraction after class. The mental space of preparation before class is divided into 4 groups; the mental space of record in class is divided into 5 groups; the mental space of extraction after class is divided into 5 groups. Each group can be divided into more details as shown in Fig. 2.

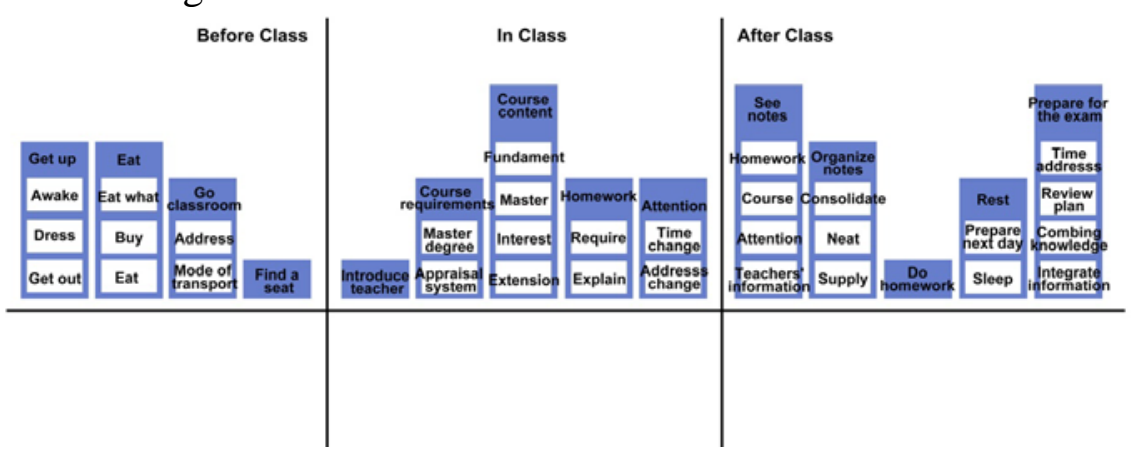

Fig. 2 Mental space of the college students’ class notes

\section{The construction of a typical scene}

Do observation research to the students' behaviors in class through observing one freshman class and one sophomore class majoring in industrial design according to the key words in the mental space(a total of nine times, including 4 times course, 5 times common class). Do interview research with 2 freshman students and 2 sophomore students according to the key words in the mental space. Construct 10 typical scenes through combining with the observation and the interview, as shown in Table 2. 
Table 2 The typical scenes overview

\begin{tabular}{|c|c|l|}
\hline $\begin{array}{c}\text { Mental } \\
\text { space }\end{array}$ & Scene & \\
\hline \multirow{3}{*}{$\begin{array}{c}\text { Before } \\
\text { class }\end{array}$} & 1 & Forget classroom address after go out \\
\cline { 2 - 3 } & 2 & Check the time to avoid to be late for class \\
\hline \multirow{4}{*}{ In class } & 3 & Not clear about the building location as a freshman \\
\cline { 2 - 3 } & 4 & Teacher introduce himself and introduce the course requirements \\
\cline { 2 - 3 } & 5 & PowerPoints turn too fast, have no time to take notes \\
\cline { 2 - 3 } & 7 & The teacher explains the homework oral, photo record is incomplete \\
\hline \multirow{3}{*}{ After class } & 8 & Concentrate on taking notes, not hear what the teacher says next \\
\cline { 2 - 3 } & 9 & Borrow class notes, add records \\
\hline
\end{tabular}

\section{The construction of a role model}

Prepare the interview outline according to the 10 typical scenes. Then interview 4 freshman students, 3 sophomore students, 3 junior students majoring in industrial design according to the interview outline ( 7 males, 3 females). Integrate and analysis the records from the interview to get 3 kinds of role model, namely self-discipline type, middle type and dependent type. The characteristics of each role model are shown in Table 3.

Table 3 The characteristics of each role model

\begin{tabular}{|c|l|l|l|}
\hline & Self-discipline type & Middle type & Dependent type \\
\hline $\begin{array}{c}\text { Before } \\
\text { class }\end{array}$ & $\begin{array}{l}\text { Learning self-discipline, } \\
\text { Well prepare before class }\end{array}$ & $\begin{array}{l}\text { Easy to be affected by } \\
\text { environmental factors, } \\
\text { Prepare before class }\end{array}$ & $\begin{array}{l}\text { Learning lazy, Seldom } \\
\text { prepare before class }\end{array}$ \\
\hline In class & $\begin{array}{l}\text { Taking notes classified, } \\
\text { Content is coherent and } \\
\text { complete }\end{array}$ & $\begin{array}{l}\text { Taking notes disorderly, } \\
\text { Content is not so clear but } \\
\text { comparatively complete }\end{array}$ & $\begin{array}{l}\text { Seldom taking notes } \\
\text { voluntarily }\end{array}$ \\
\hline After class & $\begin{array}{l}\text { Timely review, Sorting } \\
\text { review information } \\
\text { according to the review } \\
\text { plan }\end{array}$ & $\begin{array}{l}\text { Fail to timely review, } \\
\text { Review notes at the end of } \\
\text { the semester }\end{array}$ & $\begin{array}{l}\text { Fail to timely review, } \\
\text { Borrow review information } \\
\text { from classmates }\end{array}$ \\
\hline
\end{tabular}

\section{Prototype design}

We can know from the characteristics of each role model that self-discipline type and middle type are the main user type and dependent type is the secondary user type. According to the 3 kind role model characteristics, this study determines the following design points, as shown in Table 4. 
Table 4 The design points

\begin{tabular}{|c|c|}
\hline \multirow{2}{*}{$\begin{array}{l}\text { Before class (To help college } \\
\text { students go to class on time) }\end{array}$} & The campus map, helping students find the classroom \\
\hline & Remind class time, avoiding being late \\
\hline \multirow{5}{*}{$\begin{array}{l}\text { In class (To help college students } \\
\text { complete notes fast and efficiently) }\end{array}$} & Take taking photos as a notes form \\
\hline & Automatically make taking photos mute \\
\hline & Photos attached voice and text \\
\hline & Take the student schedules as the entrance of notes \\
\hline & Timely sharing of notes in class \\
\hline \multirow{4}{*}{$\begin{array}{l}\text { After class (To help college } \\
\text { students integrate and extract notes } \\
\text { efficiently) }\end{array}$} & Remind the next day class \\
\hline & Mark not reviewed notes to remind timely reviewing \\
\hline & Add the test schedule \\
\hline & Connect to the computer, convenient output at the final \\
\hline
\end{tabular}

Determine the interaction process, the steps and cohesion of the college students' class notes mobile application according to the design points. And get the framework tree through the user evaluation and internal audit. The framework tree is shown in Fig. 3.

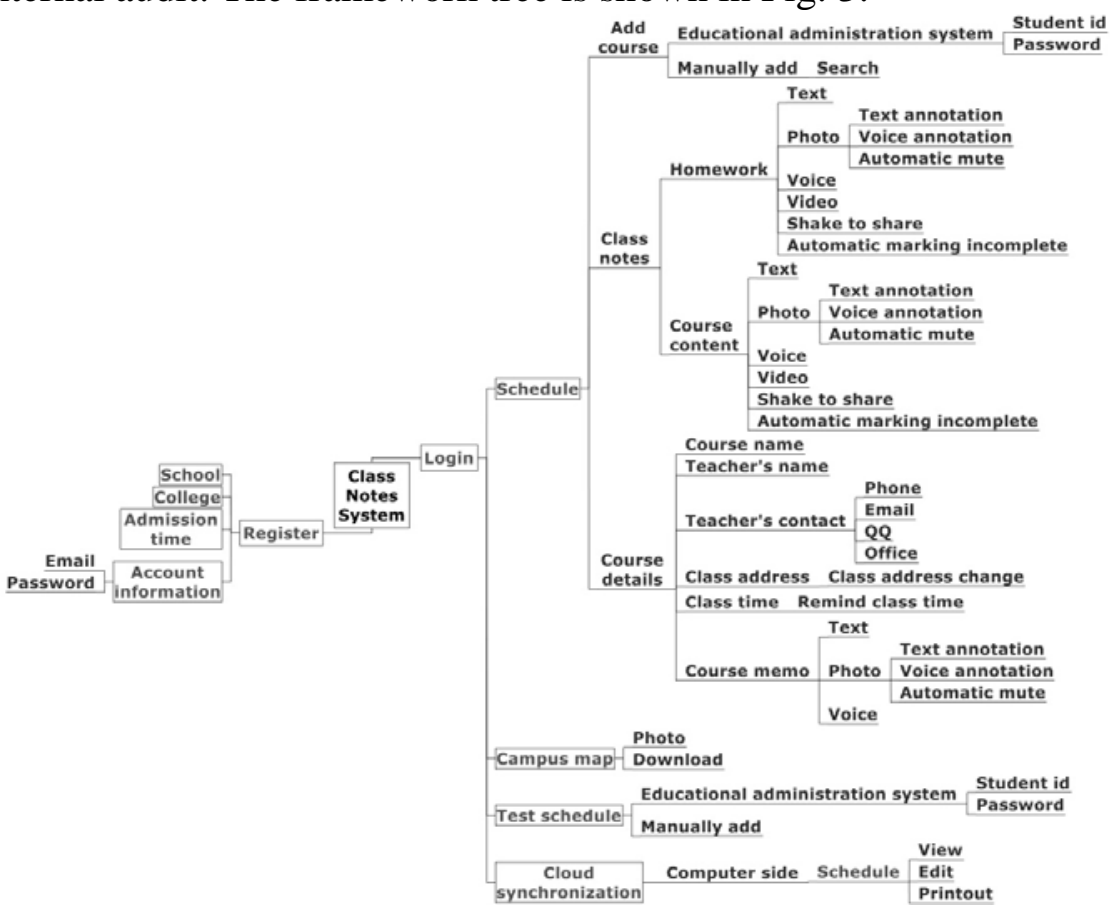

Fig. 3 The framework tree of the mobile application

Due to the limited time, the mobile application of college students' class notes is in the process of the framework tree at present. The subsequent work will be adopting the method of a paper prototype to complete the interaction process of each function and the interface of the software.

\section{Summary}

This study takes the advantages of mental model in User Research to obtain the mental models of college students' class notes by way of focus group, observation, and interview. Then guide the next design work, so the functional framework and interactive process and the other aspects of the mobile application can match the users' mental model very well and make the mobile application easy to use. Because of the time and energy, at present, this study is aimed at the art college students, the following work can expand to the other colleges.

\section{References}

[1] CRAIK. The nature of explanation [M]. Cambridge: Cambridge University Press, 1943. 
[2] DAVIDSONMJ, DOVEL, WELTZJ. Mental models and usability [M]. Chicago: Depaul University, 1999.

[3] Yang ying, Lei tian, Zhang Yan he. Handhold mobile device interface design research based on user mental model [J]. Journal of Zhejiang University (engineering science), 2008, 42(5): 800804. (In Chinese)

[4] Johnson-Laird P N. Mental models: Towards a cognitive science of language, inference and consciousness. Cambridge: Cambridge University Press; Cambridge, MA: Harvard University Press, 1983.

[5] Bai Xin wen, Wang Er ping. The current shared mental model research status [J]. Psychological Science Progress. 2004, 12(5): 791-799. (In Chinese)

[6] UE learning note: Mental model dichotomy, http://piglili.blogbus.com/logs/52720359.html

[7] Indi Young. Mental Models: Aligning Design Strategy with Human Behavior [M]. Rosenfeld Media. 2008. 